\title{
Assessment of sweet cherry (Prunus avium L.) genotypes for response to bacterial canker disease
}

\author{
Authors: Josephine Mgbechi-Ezeri, Lyndon Porter, \\ Kenneth B. Johnson, and Nnadozie Oraguzie
}

The final publication is published in Euphytica available at Springer via http://dx.doi.org/10.1007/s10681-017-1930-4.

Mgbechi-Ezeri, Josephine, Lyndon Porter, Kenneth B. Johnson, and Nnadozie Oraguzie. "Assessment of sweet cherry (Prunus avium L.) genotypes for response to bacterial canker disease." Euphytica 7 (July 2017): 1-12. DOI: 10.1007/s10681-017-1930-4. 


\title{
Assessment of sweet cherry (Prunus avium L.) genotypes for response to bacterial canker disease
}

\author{
Josephine Mgbechi-Ezeri 1 - Lyndon Porter • Kenneth B. Johnson • \\ Nnadozie Oraguzie
}

Received: 8 October 2016/Accepted: 21 June 2017/Published online: 24 June 2017

(C) Springer Science+Business Media B.V. 2017

\begin{abstract}
Integration of alleles for bacterial canker resistance into new sweet cherry cultivars requires information on the sources of resistance in the germplasm. Five market-leading sweet cherry cultivars, 'Rainier', 'Sweetheart', 'Bing', 'Regina' and 'Chelan', advanced selections 'AA', 'BB', 'CC', 'DD', 'EE', 'GG', and 'PMR-1' used as breeding parents in the Washington State University's Sweet Cherry Breeding Program were evaluated. Comparative genotypic disease severity was obtained with three methods of inoculation (leaf wounding with carborundum, cut wounds in leaf mid-rib and shoot tip) on whole plants. Additionally, genotypic data on susceptibility of detached leaves versus fruit and an assessment of the movement of Pseudomonas syringae pv. syringae (Pss) population in inoculated
\end{abstract}

J. Mgbechi-Ezeri ( $\square$ )

Department of Plant Science and Plant Pathology,

Montana State University, Bozeman, MT, USA

e-mail: josephi.mgbechiezeri@montana.edu

L. Porter

Grain Legume Genetics and Physiology Research Unit,

USDA-ARS, Prosser, WA, USA

K. B. Johnson

Department of Botany and Pathology, Oregon State

University, Corvallis, OR, USA

N. Oraguzie

Department of Horticulture, Washington State UniversityIrrigated Agriculture Research and Extension Center,

Prosser, WA, USA shoots were obtained. Genotype susceptibility was significantly $(P \leq 0.05)$ influenced by inoculation method, with shoot inoculation providing the best separation of resistance levels among genotypes. A low correlation $(\mathrm{r}=0.26, P=0.21)$ was observed between disease responses measured on detached leaf versus fruit, while a moderately high correlation ( $\mathrm{r}=0.50, P=0.10$ ) was found among bacterial populations in the tissues and in the degree of symptoms expressed. By all comparative methods, the advanced selections, as well as, 'PMR-1', were less susceptible than the market-leading cultivars. Also, movement of Pss from shoot tip inoculation points to the shoot base was not detected for advanced selections 'AA', 'BB', 'DD', and 'EE'. This study reveals that the advanced selections could be potential sources of resistance alleles to bacterial canker. This is the first evaluation of the advanced selections for bacterial canker disease.

Keywords Allele $\cdot$ Bacterial canker - Disease resistance $\cdot$ Sweet cherry $\cdot$ Pseudomonas syringae pv. syringae

\section{Introduction}

Bacterial canker, caused by Pseudomonas syringae pv. syringae (Pss) and Pseudomonas syringae pv. morsprunorum (Psm), is one of the economically 
important diseases of sweet cherry and other stone fruits worldwide (Crosse 1966; Kennelly et al. 2007; Renick et al. 2008; Vicente et al. 2004). While in some orchards both pathovars can cause bacterial canker symptoms and co-exist, strains of Pss are more virulent on sweet cherry (Kennelly et al. 2007). The pathogen attacks various parts of the tree and the disease is recognized by a variety of symptoms depending upon the part of the plant being attacked (Moore 1988). These symptoms include trunk and branch cankers, gummosis, blossom blast, twig blight, shoot dieback and leaf shot hole (Moore 1988). Moreover, the pathogen has a wide host range and lives as an epiphyte on numerous plants without producing symptoms. For susceptible cultivars, the ubiquitous nature of Pss makes it potentially destructive whenever favorable environmental conditions occur (Cameron 1970; Kennelly et al. 2007). These conditions include prolonged wetness and frost-induced wounding (Moore 1988; Otta and English 1970; Sobiczewski and Jones 1992). In the USA, losses of sweet cherry trees to bacterial canker have approached 75\% in Oregon (Cameron 1962) and Michigan (Renick et al. 2008).

Management of bacterial canker in susceptible sweet cherry cultivars is frequently unachievable due to lack of effective chemical control and the epiphytic nature of the pathogen (Kennelly et al. 2007). Likewise, cultural control practices such as removal of infected twigs/trees, summer pruning and soil amendment can only reduce symptoms but does not eliminate populations of the pathogen (Spotts et al. 2010a). Conversely, the use of resistant scion and rootstock cultivars holds promise as a sustainable and cost effective method of bacterial canker control. But, it is also frustrating due to limited availability of resistant cutivars and challenges with screening methods to distinguish levels of resistance within the breeding population. Previously, various methodologies have been employed to assess the resistance of sweet cherry scion and rootstock cultivars to Pss. Bedford et al. (2003) evaluated two inoculation methods (leaf disc infiltration and mid-rib wound injection) in a detached leaf assay to differentiate disease response among sweet cherry cultivars. This study revealed failure of leaf disc infiltration to discriminate disease response among cultivars. Spotts et al. (2010b) who compared the resistance of five sweet cherry cultivars based on seven inoculation methods showed that susceptibility of sweet cherry cultivars was significantly influenced by inoculation method, and that cvs. 'Regina' and 'Rainier' were tolerant to Pss infection. This was contrary to Roche (2001) who observed that 'Rainier' was highly susceptible to Pss based on an excised twig assay. Garrett (1986), in an investigation of the influence of rootstock on susceptibility of sweet cherry reported variation in susceptibility of cultivars based on methods of inoculation. Overall, these past studies demonstrate variability when attempting to characterize the tolerance/resistance and susceptibility of sweet cherry selections to bacterial canker. This variability likely stems from inoculation method, pathogen strain and type of plant materials utilized for experiments as well as the environment.

Development of new sweet cherry cultivars is an ongoing activity. Consequently, continuous assessment of disease resistance in breeding germplasm is necessary to maintain and enhance the utility, durability and acceptance of new cultivar releases. Previous studies have evaluated resistance of some sweet cherry cultivars to economically important diseases including powdery mildew and bacterial canker. Toyama et al. (1993) found that the sweet cherry cultivar 'PMR-1', originating from an open-pollinated seedling, was resistant to powdery mildew disease. In 2001, Olmstead et al. conducted a study on the inheritance of powdery mildew resistance among progenies from biparental crosses and their reciprocals including sweet cherry cultivars, 'PMR-1' $\times$ 'Bing'/ 'Rainier'/ and 'Van'. Subsequently, Zhao (unpublished) concluded that genotypes including 'AA', 'BB', 'CC', 'DD', 'EE' and 'GG' from Olmstead et al.'s study were resistant to powdery mildew disease, which, combined with average fruit quality, elevated these genotypes to advanced selection status in the Washington State University breeding program. Moreover, in an evaluation of 600 sweet cherry genotypes, selections 'AA', 'BB', 'CC', 'DD', 'EE' and ' $\mathrm{GG}$ ' also showed a low response to bacterial canker disease based on a mid-rib inoculation in a detached leaf assay (Mgbechi-Ezeri 2016). To date, no other studies have evaluated these selections for resistance to bacterial canker. For the current study, we collected comparative genotypic data on susceptibility to bacterial canker based on whole plant inoculation of Pss into three types of wounds: leaf wounds created with carborundum, cut leaf mid-ribs, and cut shoot tips. In addition, we compared disease 
responses among detached leaves and detached fruit following inoculation, and correlated the size of the pathogen population in the stem tissue with degree of symptom expression. The overarching goal of the study was to develop methods to accurately identify sweet cherry genotypes resistant to bacterial canker for use as parents in the breeding of new sweet cherry cultivars for the Pacific Northwest regions of United State of America.

\section{Materials and methods}

\section{Plant materials}

Six advanced selections 'AA', 'BB', 'CC', 'DD', 'EE', 'GG' (from 'PMR-1' $\times$ 'Rainier' or the reciprocal cross) (Olmstead et al. 2001) and their parent, 'PMR-1', were chosen for this study based on their low disease response to bacterial canker in a previous detached leaf assay (Mgbechi-Ezeri 2016). Also, chosen for evaluation were five market-leading cultivars ('Regina', 'Sweetheart', 'Rainier', 'Bing' and 'Chelan'), which are known to be moderately to highly susceptible to bacterial canker (Bedford et al. 2003; Mgbechi-Ezeri et al. 2013; Spotts et al. 2010b). All plant materials originated from the United States, and are maintained by the Washington State University sweet cherry breeding program (WSU-SCBP) located at Irrigated Agriculture Research and Extension Center, Prosser, WA. Based on previous studies, the advanced selections and 'PMR-1' have been identified as sources of powdery mildew resistance and used as parents for powdery mildew resistant breeding in the WSU-SCBP (Toyama et al. 1993; Zhao unpublished). For this study, scions of all genotypes were budded onto 'Mazzard' rootstocks (14.3 mm thickness) that had been propagated by a commercial nursery and received as dormant bare rooted trees covered with wood shavings. Budded rootstocks (four buds per rootstock and two plants per genotype) were transplanted into 15-1 plastic pots containing Nulife ProBlend potting soil (Waupaca, WI, USA) and grown under $12 \mathrm{~h}$ of light (fluorescent bulb) in the greenhouse. Trees were budded in early January (2014 and 2015) for a spring inoculation experiment and again in early November (2014) for a winter inoculation experiment. After budding, trees were maintained in the greenhouse at a temperature between 22 and $25{ }^{\circ} \mathrm{C}$ and allowed to grow for approximately 6 weeks before inoculation. Budded rootstocks were watered regularly as needed, and fertilized after bud break (using Miracle Gro ${ }^{\circledR}$ All-purpose plant food, 24-8-16, Scots Co., Marysville, $\mathrm{OH}$ ) until the experiment was concluded.

Bacterial strain and inoculum preparation

Pseudomonas syringae pv. syringae, Pss 425, isolated previously from a diseased sweet cherry tree located near the Dalles, OR, as was obtained from Department of Botany and Plant Pathology, Oregon State University, Corvallis. Pss 425 was further characterized with LOPAT (Levan production, oxidase activity, potato soft rot, arginine dihydrolase activity and hypersensitivity on tobacco) and GATTa (gelatin liquefaction, aesculin hydrolysis, tyrosinase activity and utilization of tartrate) tests (Lelliott and Stead 1987), and confirmed for syringomycin production by polymerase chain reaction (PCR) with primer pair PSSB1 and PSSB2 (Sorensen et al. 1998). This bacterial strain was chosen due to its high virulence compared to five other Pss strain in preliminary inoculation of several sweet cherry cultivars (Mgbechi-Ezeri unpublished). A loopful $(10 \mu \mathrm{l})$ of bacterial culture grown for $48 \mathrm{~h}$ on a Pseudomonas Agar F (PAF, Difco Labs, Detroit, MI) amended with $50 \mu \mathrm{g} /$ ml cycloheximide (Sigma-Aldrich C7698-5G) was transferred to a sterile nutrient broth $(15 \mathrm{ml})$ and agitated on a rotary shaker for $24 \mathrm{~h}$ at $200 \mathrm{rpm}$ and $28{ }^{\circ} \mathrm{C}$. Bacterial cells were harvested by centrifugation at $7000 \mathrm{rpm}$ for $5 \mathrm{~min}$, re-suspended in sterile distilled water (SDW) and adjusted to cell densities of $10^{8} \mathrm{cfu} / \mathrm{ml}$ (absorbance at $600 \mathrm{~nm}=0.3$ ). Bacterial cell counts were confirmed by dilution plate method on a PAF medium and then $0.5 \%$ of surfactant (BreakThru ${ }^{\circledR}$ S 240, Evonik Industries, Essen, Germany) was added to the inoculum before inoculation. SDW mixed with $0.5 \%$ surfactant was used as a negative control except for inoculation by carborundum where $0.05 \mathrm{~g}$ carborundum powder plus SDW was used.

Experiment 1: comparison of inoculation methods

In the greenhouse, disease responses of 12 sweet cherry genotypes were compared in whole plant assays after inoculation of Pss into three types of wounds: leaf 
wounds created with carborundum, cut leaf mid-ribs, and cut shoot tips.

\section{Carborundum inoculation}

The first, second and third leaves from the apical growing point of the shoot of each genotype were surface sterilized with $70 \%$ ethanol for about $30 \mathrm{~s}$ and rinsed with SDW. The leaves were inoculated by rubbing a sterile cotton swab (Q-tips cotton swab, Unilever, USA) dipped in a $10^{8} \mathrm{cfu} / \mathrm{ml}$ suspension of Pss 425 mixed with $0.05 \mathrm{~g}$ carborundum powder (320 grit, Alfa Aesar ${ }^{\circledR}$, Johnson Matthey, Ward Hill, MA) on the abaxial side of the leaf from the distal to proximal edges twice. Water plus $0.05 \mathrm{~g}$ carborundum was used as a negative control. Inoculated leaves were enclosed with a plastic bag containing sterile cotton balls soaked in SDW for $48 \mathrm{~h}$ to create a $100 \%$ relative humidity environment suitable for the pathogen to initiate infection. Disease severity was recorded at 8 days post inoculation (dpi) based on a 5-point scale adapted from Bedford et al. (2003) (Table 1).

\section{Mid-rib inoculation}

The first, second and third leaves from the apical growing point of the shoot of each genotype were surface sterilized as described above. The leaves were inoculated by carefully slitting the mid-rib to about $1 \mathrm{~mm}$ in depth from the petiole to the apex on the underside of the leaf using a sterile scalpel (blade size 11, Bard-Parker ref: 371311) and applying $10 \mu \mathrm{l}$ of the Pss 425 suspension $\left(10^{8} \mathrm{cfu} / \mathrm{ml}\right)$ to the wounded area. On control plants, leaves were inoculated with an equal volume of sterile distilled water. The inoculated leaves were enclosed within plastic bags containing sterile cotton balls as described above. Disease severity was recorded at $8 \mathrm{dpi}$ based on a 5-point scale (Table 1).

\section{Shoot inoculation}

Shoots were inoculated by cutting the tip about $20 \mathrm{~mm}$ in length with a sterile razor blade to which $10 \mu \mathrm{l}$ of Pss $425\left(10^{8} \mathrm{cfu} / \mathrm{ml}\right)$ was applied directly on top of the wound. Wounds were covered with plastic bags containing sterile cotton balls as described above. The cotton balls were prevented from contact with the inoculation site. Necrotic lesion length was measured after 8 weeks, and disease severity was rated on a 5-point scale (Table 1) (Santi et al. 2004).

The wounding experiment was arranged in completely randomized experimental design with five replicates of two plants per genotype. Experimental trees were spaced $300 \mathrm{~mm}$ between pots and maintained in the greenhouse at $15^{\circ} \mathrm{C}$. Each method of inoculation was applied to one of the grafted shoots on each tree; the shoot that emerged from the fourth bud was used as a negative control. The experiment was conducted three times: spring 2014, winter 2014 and spring 2015.

Experiment 2: correlation between detached fruit and foliar disease responses

The protocol of Latorre et al. (2002) was used for inoculation of detached immature fruit. In May, 10 immature fruit (light green stage) from each of the

Table 1 Rating scale and disease response categorization of sweet cherry genotypes to infection by Pseudomonas syringae pv. syringae

\begin{tabular}{|c|c|c|c|c|}
\hline $\begin{array}{l}\text { Rating } \\
\text { scale }\end{array}$ & $\begin{array}{l}\text { Greenhouse rating (Bedford et al. } \\
\text { 2003) }\end{array}$ & Laboratory rating (Roche 2001). & Fruit rating (Moragrega et al. 2003) & $\begin{array}{l}\text { Disease } \\
\text { category }\end{array}$ \\
\hline 0 & Free from infection & No necrosis & No necrosis & Resistant \\
\hline 1 & $1-25 \%$ of shoot infected & $\begin{array}{l}\text { Necrosis restricted to line of } \\
\text { infection }\end{array}$ & $\begin{array}{l}\text { Necrosis restricted to the point of } \\
\text { infection }\end{array}$ & Low \\
\hline 2 & $\geq 26$ to $\leq 50 \%$ of shoot infected & Necrosis $\leq 50 \%$ of leaf area & $\begin{array}{l}\text { Necrotic area }<5 \mathrm{~mm} \text { diameter on } \\
\text { fruit }\end{array}$ & Moderate \\
\hline 3 & $\geq 50$ to $\leq 75 \%$ of the shoot & Necrosis $>50 \%$ of leaf area & $\begin{array}{l}\text { Necrotic area } 5-10 \mathrm{~mm} \text { diameter on } \\
\text { fruit }\end{array}$ & High \\
\hline 4 & $\begin{array}{l}>75 \% \text { of the shoot infected/death } \\
\text { of tree }\end{array}$ & Total necrosis of leaf & $\begin{array}{l}\text { Necrotic area }>10 \mathrm{~mm} \text { diameter on } \\
\text { fruit }\end{array}$ & High \\
\hline
\end{tabular}


twelve genotypes were detached from fruit-bearing trees planted at the WSU Roza Experimental Orchard Prosser, WA. (All scion genotypes were grown on a 'Gisela 6' rootstock except 'Chelan' and 'PMR-1', which were on a 'Mazzard' rootstock). The fruits were surface sterilized with $70 \%$ ethanol for $30 \mathrm{~s}$, rinsed in two changes of SDW and blotted dry with three layers of sterilized paper towels. Each fruit was punctured with a sterile scapel blade size 11 to a depth of about $1 \mathrm{~mm}$, and inoculated with $10 \mu \mathrm{l}$ of $10^{8} \mathrm{cfu} / \mathrm{ml}$ bacterial suspension. Following inoculation, fruit were placed in plastic boxes containing three layers of moist sterile paper towel and incubated at room temperature for 8 days. Control fruit of each genotype were inoculated with SDW. The experiment was arranged in a completely randomized design with three replicates per genotype; the experiment was conducted in 2014 and repeated in 2015. Disease symptom expression and progression was scored using a 5-point scale (Moragrega et al. 2003) (Table 1) at 8 dpi. To compare disease responses from fruit to foliar responses, 10 new leaves from the tip of each genotype were collected from the orchard along with the immature fruit. Detatched leaves were inoculated with Pss 425 following the cut mid-rib protocol as described above. After inoculation, these leaves were incubated in plastic boxes lined with moistened paper towel as described above, and scored for disease response at 8 dpi.

Experiment 3: correlation between pathogen population size in tissue and symptom expression

At 8 weeks after inoculation, $200 \mathrm{~mm}$ lengths of sweet cherry shoots that had been inoculated with Pss 425 following the shoot tip protocol (described above) were harvested. On each shoot, a $10 \mathrm{~mm}$ length $\times 2 \mathrm{~mm}$ stem thickness piece of tissue was sampled from three areas of the stem. The positions were labeled as top (area circumscribing infection), middle (area between the infected region and the base of the shoot) and base (area located at the base of the shoot with no visible symptom). Removed tissue was placed in Ziploc bags and kept on ice in a cooler for transport to the laboratory and processed immediately. Tissue from non-inoculated shoots also was sampled similarly to represent a negative control. Each tissue piece (approximately $0.1 \mathrm{~g}$ ) was soaked in $1 \mathrm{ml}$ of SDW for about $6-8 \mathrm{~h}$ at room temperature, tenfold dilutions were prepared and $1 \mathrm{ml}$ aliquots of $10^{6}$ dilution (based on preliminary study) was spread on PAF plates amended with $50 \mu \mathrm{g} / \mathrm{ml}$ cycloheximide in three replicates per sample. The plates were incubated at $28{ }^{\circ} \mathrm{C}$ and colonies counted after $72 \mathrm{~h}$ to calculate the $\mathrm{CFU} /$ gram of infected tissue. A 4-point rating scale (0-3) was applied to describe bacterial advancement where, $0=$ no bacterial cells detected, $1=$ bacterial cells detected at the top, $2=$ bacterial cells detected mid-way, and $3=$ bacterial cells detected at the base.

Statistical analysis

All experiments were analyzed by analysis of variance (ANOVA) in SAS 9.4 (SAS Institute Inc., Cary, NC, USA) (2014). A Bartlett's test was used to test for homogeneity of variances before combining the data from different years (e.g., spring 2014, winter 2014 and spring 2015). ANOVA was used to examine the disease response of each genotype and how the inoculation methods differentiated disease responses among genotypes. The means were separated by Tukey's Studentized Range (HSD) test $(P=0.05)$. Pearson's correlation coefficient was used to compare disease responses among detached fruits and detached leaves, as well as, to compare pathogen advancement in stem tissue with severity of symptom expression. Pathogen population sizes, was estimated using the formula CFU/g $=$ number of colonies counted $\times$ dilution factor /volume of culture plated. The resulting colony forming unit was log transformed to get the Log CFU then analyzed by ANOVA.

\section{Results}

Bacterial strain

The bacterial strain used in the experiments, Pss 425 , produced levan, induced hypersensitive reaction on tobacco leaves, hydrolyzed gelatin and aesculin but was negative for oxidase, arginine dihydrolase, potato soft rot, tyrosinase activity and utilization of tartaric acid $(+-+$ reaction for LOPAT and ++ -for GATTa test) (Lelliot et al. 1966; Schaad et al. 2001). A PCR product size of $752 \mathrm{bp}$ specific for the $s y r \mathrm{~B}$ gene encoding syringiomycin secretion was amplified. Overall, these results confirmed the identification of the bacterial strain as Pss. 
Comparison of inoculation methods

Disease response among genotypes differed significantly $(P \leq 0.05)$ by inoculation method, although all the plants challenged with Pss 425 were infected regardless of inoculation protocol (Fig. 1). A brown discoloration was observed on negative controls at the point(s) of wounding but did not progress beyond the injury site. Homogeneity of variance (evaluated with a Bartlett's test) revealed no significant differences in overall disease response among experiments performed at different times (mid-rib: $P=0.33$; carborundum; $P=0.2$ and shoot; $P=0.25$ ). Initial necrotic symptoms were observed on all genotypes at 2, 4 and 14 dpi for mid-rib, carborundum and shoot inoculations, respectively. All genotypes inoculated by carborundum had low disease scores that ranged from 0.9 and 1.3 (Fig. 2); although genotype was a significant influence on measured values $(P \leq 0.05)$. In contrast, disease scores for mid-rib inoculation ranged between 1.7 and 3.1, potentially indicating a greater differentiation of resistance and susceptibility to bacterial canker (Fig. 2). The disease rating of 'Rainier' and 'Sweetheart' were significantly $(P \leq 0.05)$ higher than those for 'Bing' and 'Chelan', whereas 'Regina', 'PMR-1', as well as, the advanced selections were not significantly different $(P \geq 0.05)$ from each other (Fig. 2). With shoot inoculation, the lesion length ranged between 18.05 and $58.54 \mathrm{~mm}$. Disease progression and severity were significantly $(P \leq 0.05)$ higher in 'Sweetheart' 'Rainier' and 'Bing' than in 'Chelan' and 'Regina', while the advanced selections were the most resistant (Fig. 3). Although the advanced selections showed no differences in disease response amongst themselves, they did show reduced infection compared to the marketleading cultivars and to their parent 'PMR-1'.

Correlation between detached fruit and foliar disease response

Severity of symptom on sweet cherry genotypes after inoculation with Pss differed among fruit and leaves. The average disease score for immature fruit was significantly greater $(P \leq 0.05)$ than in the leaves (Fig. 4), and none of the inoculated fruit were scored as resistant. Analysis of variance showed no significant differences $(P \geq 0.05)$ in the effect of year or genotype $\times$ year interaction on the disease response of both fruit and leaf (Table 2). For specific genotypes,

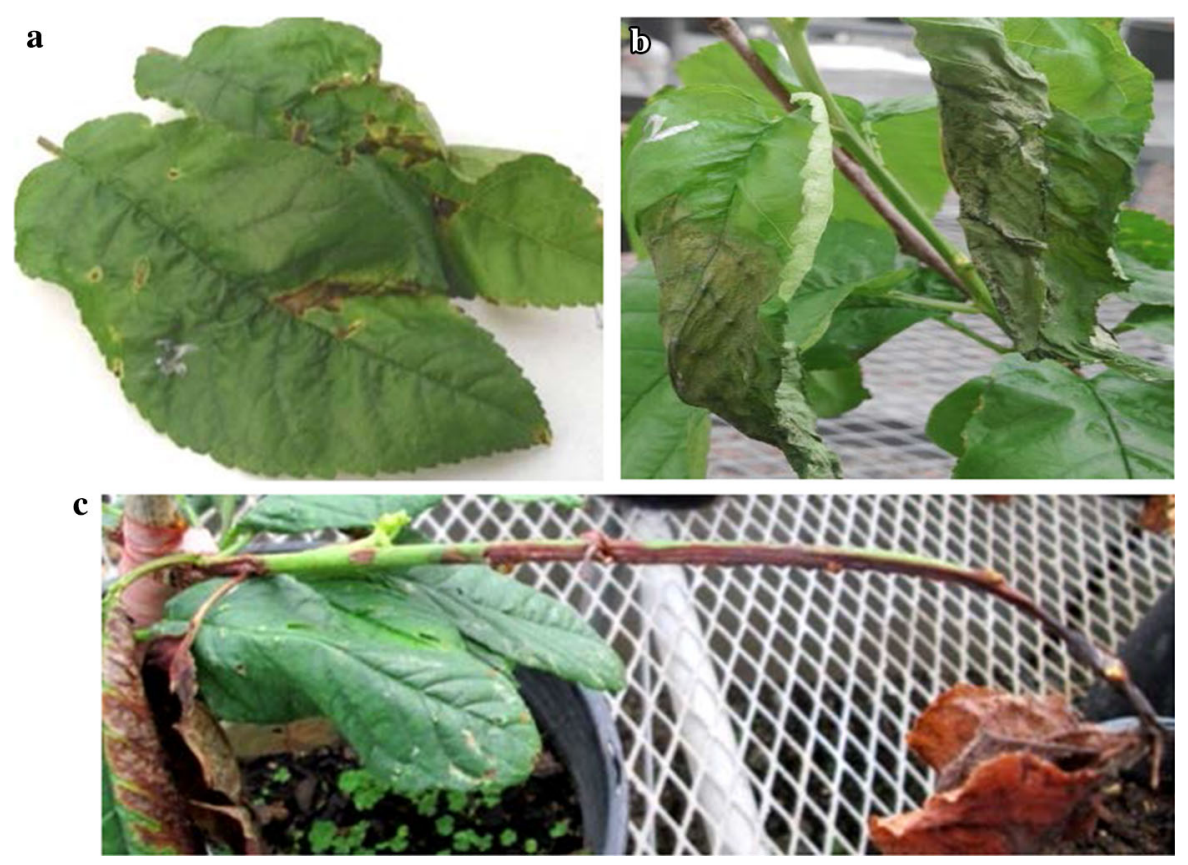

Fig. 1 Necrotic symptoms observed on sweet cherry genotypes inoculated with Pseudomonas syringae pv. syringae strain Pss 425. a Leaf symptom 8 days after inoculation using carborundum inoculation, b leaf symptom 8 days after inoculation using mid-rib inoculation, and $\mathbf{c}$ shoot symptoms 8 weeks after inoculation using shoot tip wounding method 


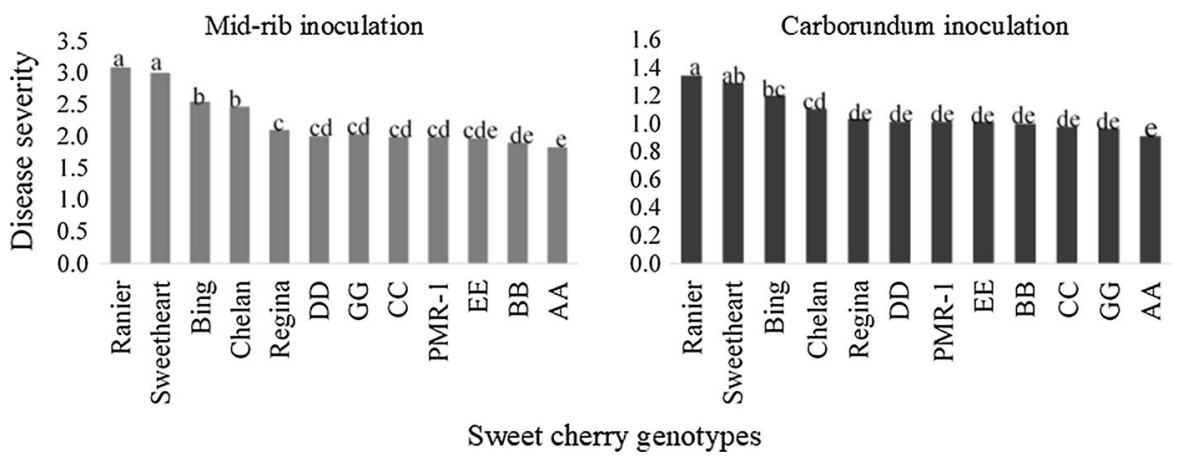

Fig. 2 Comparison of mid-rib and carborundum methods of inoculation with Pseudomonas syringae pv. syringae strain Pss 425 based on disease ratings of 12 sweet cherry genotypes to bacterial canker. Bars labelled with the same letters within inoculation methods are not significantly different based on Tukey's Studentized Range Test (HSD). Disease severity was rated 8 days post inoculation. The experiment was conducted three times (spring 2014, winter 2014 and spring 2015), and the means were combined across experiments due to lack of significant differences $(P \geq 0.05)$ between genotypic values across experiments

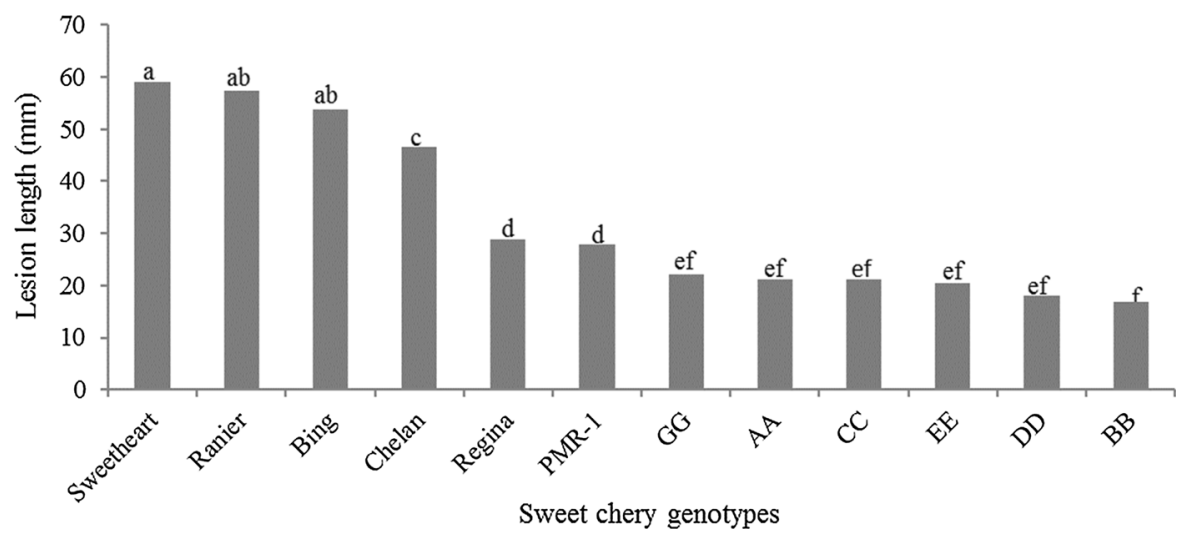

Fig. 3 Length of necrotic lesions on shoots of 12 sweet cherry genotypes inoculated with Pseudomonas syringae pv. syringae strain Pss 425 and observed at 8 weeks after inoculation. Bars labeled with the same letters are not significantly different based on Tukey's Studentized Range (HSD) Test at $P=0.05$. The

'Regina' had the highest disease scores (3.2 and 1.3 for fruit and leaf, respectively) while 'EE' had the lowest score (2.3 and 1.1, respectively). Genotypic scores for the detached leaf and fruit assays were only weakly correlated $(\mathrm{r}=0.26, P=0.21)$.

Correlation between bacterial population density and symptom expression

Pathogen population size within diseased shoots varied among genotypes and position of the sample taken from the inoculated shoot. Overall, population size of Pss 425 was reduced significantly $(P \leq 0.05)$ in advanced selections compared to market-leading experiment was conducted three times (spring 2014, winter 2014 and spring 2015), and the means were combined across experiments due to lack of significant differences $(P \geq 0.05)$ among genotypic values across experiments

cultivars (Table 3). At the shoot tip (site of inoculation), pathogen population size differed significantly $(P \leq 0.05)$ among advanced selections and 'PMR-1'. 'EE' had a relatively low pathogen population (log $(\mathrm{cfu} / \mathrm{g})=7.59 \pm 0.02)$ while 'AA' had the highest $(\log (\mathrm{cfu} / \mathrm{g})=8.18 \pm 0.01)$ pathogen population. Among the market-leading cultivars, pathogen population size did not vary significantly $(P \geq 0.05)$ with 'Chelan' having the lowest population size (Table 3). At this sampling position, the overall pathogen population was relatively high in all genotypes challenged with Pss.

For stem tissue collected from the middle of the diseased shoots, internal discoloration of the vascular 


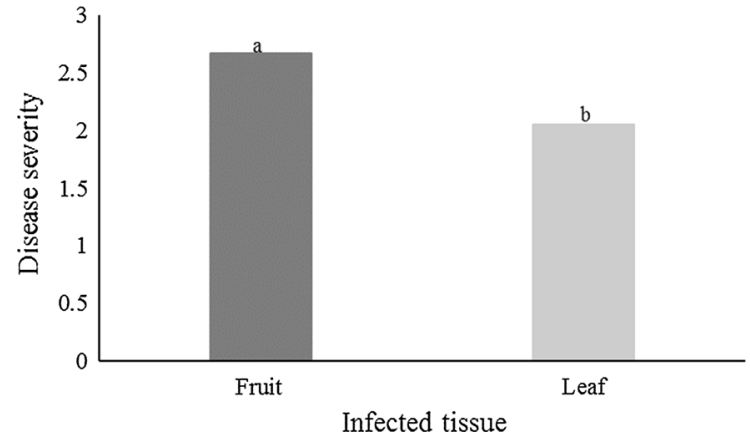

Fig. 4 Comparison of detached fruit and foliar disease response under laboratory conditions after inoculation of sweet cherry genotypes with Pseudomonas syringae pv. syringae strain Pss 425 . Prior to inoculation, leaves were wounded by creating a cut of about $1 \mathrm{~mm}$ in depth in the mid-rib and fruit were wounded with a puncture of about $1 \mathrm{~mm}$-depth into the flesh. Both tissues were inoculated with $10 \mu \mathrm{l}$ of $10^{8} \mathrm{cfu} / \mathrm{ml}$ bacterial suspensions and incubated on a moist sterile paper towel. Disease response was scored 8 days after inoculation. The experiment was repeated twice. Since no significant differences $(P \geq 0.05)$ were found between values across experiments using a $T$-test, a single mean value was obtained per tissue type and compared

Table 2 Analysis of variance (ANOVA) of the disease response of 12 sweet cherry genotypes inoculated with Pseudomonas syringae pv. syringae strain Pss 425 in 2 years (2014 and 2015) and in two different tissues (leaf and fruit) in a detached assay

\begin{tabular}{lrll}
\hline Source & \multicolumn{3}{l}{ Mean square } \\
\cline { 2 - 4 } & DF & Leaf & Fruit \\
\hline Genotype & 11 & $6.17 * * *$ & $0.5^{* * * *}$ \\
Year & 1 & 0.02 & 0.13 \\
Genotype $\times$ year & 11 & 0.17 & 0.03 \\
Error & 24 & 0.13 & 0.04 \\
\hline
\end{tabular}

Experiment was conducted in the laboratory with detached fruit (light green stage) and leaves collected from the same tree in the field. Disease was scored on a $0-4$ scale

*** Significant at $P \leq 0.0001$

tissue was observed in most genotypes. Pathogen population size varied significantly $(P \leq 0.05)$ among the advanced selections and 'PMR-1' although this was greatly $(P \leq 0.05)$ reduced compared to the market-leading cultivars with no substantial $(P \geq$ $0.05)$ variation in pathogen population size. At the base of the shoots, no visual symptom of infection was observed during sampling. Also, bacterial cells were not detected in advanced selections including 'AA',
Table 3 Population size of Pseudomonas syringae pv. syringae strain Pss 425 at different shoot locations on inoculated shoots from 12 sweet cherry genotypes on a 'Mazzard' rootstock

\begin{tabular}{lllll}
\hline Genotypes & Source & \multicolumn{3}{l}{ Sampling location $^{\mathrm{a}}$} \\
\cline { 3 - 5 } & & Top $^{\mathrm{c}}$ & Middle & Base $^{\mathrm{d}}$ \\
\hline Bing & WSU-SCBP & $7.90 \mathrm{c}$ & $7.78 \mathrm{a}$ & $7.19 \mathrm{a}$ \\
Chelan & WSU-SCBP & $7.81 \mathrm{~d}$ & $7.59 \mathrm{ab}$ & $6.70 \mathrm{ab}$ \\
PMR-1 & WSU-SCBP & $7.71 \mathrm{e}$ & $7.13 \mathrm{~cd}$ & $6.73 \mathrm{ab}$ \\
Rainier & WSU-SCBP & $7.93 \mathrm{c}$ & $7.85 \mathrm{a}$ & $6.56 \mathrm{ab}$ \\
Regina & WSU-SCBP & $7.91 \mathrm{c}$ & $7.78 \mathrm{a}$ & $7.11 \mathrm{ab}$ \\
Sweetheart & WSU-SCBP & $7.90 \mathrm{c}$ & $7.84 \mathrm{a}$ & $7.30 \mathrm{a}$ \\
AA & WSU-SCBP & $8.18 \mathrm{a}$ & $6.10 \mathrm{~g}$ & ND c \\
BB & WSU-SCBP & $7.74 \mathrm{de}$ & $6.84 \mathrm{def}$ & ND c \\
CC & WSU-SCBP & $7.70 \mathrm{e}$ & $6.49 \mathrm{fg}$ & $4.10 \mathrm{~b}$ \\
DD & WSU-SCBP & $8.09 \mathrm{~b}$ & $6.59 \mathrm{ef}$ & ND c \\
EE & WSU-SCBP & $7.59 \mathrm{f}$ & $6.96 \mathrm{cde}$ & ND c \\
GG & WSU-SCBP & $7.75 \mathrm{de}$ & $7.30 \mathrm{bc}$ & $6.69 \mathrm{ab}$ \\
\hline
\end{tabular}

a Sampling location on shoot where top means tissue samples collected from the shoot tip region circumscribing necrotic lesions, middle indicates samples collected half way between the infected shoot tip and the base while base means the base of the shoot. Total shoot length was approximately $200 \mathrm{~mm}$

b WSU-SCBP, Washington State University sweet cherry breeding program. All plant materials originated from the USA

c Bacterial count in cfu/g of infected stem tissue transformed into $\log (\mathrm{cfu} / \mathrm{g})$. Values followed by the same letters within column are not significantly different at $P \leq 0.05$ based on Tukey's Studentized Range Test (HSD). Bacterial populations were determined using the dilution plate count method on PAF plates amended with $50 \mu \mathrm{g} / \mathrm{ml}$ cycloheximide and incubated at $28^{\circ} \mathrm{C}$ for $72 \mathrm{~h}$ in three replicates

${ }^{\mathrm{d}} \mathrm{ND}$ indicates bacterial cell was not detected at a dilution of $1 \times 10^{6}$ (dectection limit)

'BB', 'DD' and 'EE', while, among the marketleading cultivars there was no significant variation $(P \geq 0.05)$ in the population of Pss . A moderately high correlation $(\mathrm{r}=0.50, P=0.10)$ was observed between pathogen population size and lesion length in the genotypes.

\section{Discussion}

In our earlier study (Mgbechi-Ezeri 2016), use of a detached leaf assay to screen a large populations of sweet cherry genotypes for disease response to bacterial canker showed that the selections 'AA', 
'BB', 'CC', 'DD', 'EE', 'GG' as well as, 'PMR-1' had a low disease response. In this study, we used whole plant assays to determine the disease response of these advanced selections and important market cultivars of sweet cherry. Three inoculation methods were evaluated to determine the response of 12 genotypes to infection. Disease symptoms including leaf necrosis (mid-rib and carborundum) and shoot dieback were observed on all inoculated plants; disease response however, varied by genotype and inoculation method. All genotypes inoculated by carborundum showed relatively low levels of disease indicating that this method may not be suitable for differentiating genotypes for susceptibility or resistance to infection. This result is in line with the inability of carborundum inoculation to induce bacterial blight symptoms in cotton genotypes following inoculation with Xanthomonas axonopodis (Eddin et al. 2005). With leaf mid-rib inoculation, the distinction in the level of disease response observed among genotypes was improved compared to wounding with carborundum. The disease scores in the advanced selections including 'AA', 'BB', 'CC', 'DD', 'EE', 'GG' as well as, 'PMR-1' were significantly lower than in the cultivars except for 'Regina'. The cultivars 'Rainier', and 'Sweetheart' were more susceptible to bacterial canker compared to 'Bing' and 'Chelan' This result agrees with previous findings where cv. 'Rainier', 'Sweetheart' and 'Bing' were susceptible to bacterial canker in detached leaf assays in the laboratory (Bedford et al. 2003; Mgbechi-Ezeri et al. 2013; Roche 2001). Compared to mid-rib and carborundum inoculations, the shoot inoculation method resulted in the greatest differentiation of disease response among the advanced selections and their parent, 'PMR-1', as well as, among the common market cultivars. Consequently, we conclude that this method will be most suitable for validating the resistance or susceptibility of breeding materials.

The economic importance of a disease depends on the rate at which it progresses on the plant and limits yield (Keane and Kerr 1997). Identifying an evaluation method that can differentiate the rate of disease progression among sweet cherry genotypes for potential use as breeding parents is essential in breeding programs. This study showed that disease progression and severity varied among the twelve genotypes evaluated. For example, 'Sweetheart', 'Rainier' and 'Bing' were more susceptible to Pss than other cultivars. This concurs with Bedford et al. (2003), Mgbechi-Ezeri et al. (2013) and Roche (2001) who had previously reported that 'Rainier' was susceptible in detached leaf and twig assays, while (Spotts et al. 2010b) demonstrated that 'Rainier' was tolerant in an orchard experiment. A likely reason for the discrepancy in reports may be the environment where studies were conducted and/or the bacterial strain used in the studies. In detached leaf assays or in a greenhouse environment, relative humidity is usually higher but the environment is much more controlled than in orchard environments. Disease progression under high humidity is likely to be greater than in a dry environment as the field (Latorre et al. 1985). In all inoculation methods, 'Regina' showed a low disease response to Pss, a finding that agrees with (Spotts et al. 2010b). Disease progression on 'Chelan' varied with inoculation method. This suggests that under favorable conditions, 'Chelan' may display susceptibility to Pss. All the advanced selections plus 'PMR-1' consistently showed low disease progression in all three inoculation methods suggesting that these genotypes may have some level of resistance hence may be potential parents for bacterial canker resistance breeding. These results concur with our previous laboratory screening based on a detached leaf assay (MgbechiEzeri 2016). Further evaluation in the field however, under different environmental conditions may be necessary to confirm their resistant status.

Other studies have suggested that the contrasting response of fruit and leaf to infection may be due to different genetic factors controlling disease reaction in these tissues (Walker and Bosland 1999; Werner et al. 1986). In this study, we observed significant differences in disease response between immature fruit and leaf tissues. One possible explanation for this difference could be the moisture level and amount of substrate available in the fruit supporting rapid bacterial growth, which may be lacking in the leaf. The result concurs with Werner et al. (1986) who showed a low correlation between the fruit and leaf to bacterial canker infection in peach and nectarine. In addition, significant differences in disease response were observed between different parts of tomato plants infected by Phytohpthora capsici (QuesadaOcampo and Hausbeck 2010). It may be essential to incorporate disease resistance alleles from both tissue types into new cultivars rather than from one tissue type alone. 
Two basic ideas proposed to guide the description of plant disease resistance include: (1) visual symptom is a direct consequence of the amount of pathogen present in a host, and (2) pathogen growth and development is interrelated with the host's defense mechanism and the host's ability to recognize the pathogen and activate the defense genes (Kover and Schaal 2002). Some past studies have shown discrepancies in the findings for the relationship between symptom expression and bacterial population size. For example, Vanneste et al. (2013) reported a low correlation between endophytic population size of Pseudomonas syringae pv. actinidiae (Psa) and length of necrosis while Shane and Baumer (1987) documented a high positive correlation between symptom expression and population size of Pseudomonas syringae pv. syringae in wheat. In our study, we observed a moderatetly high correlation between visual symptom expression and bacterial population size. This suggests that applying visual assessments of necrotic symptoms alone in the evaluation of genotypes for breeding may not be very efficient for selecting bacterial canker resistant genotypes. The ability to detect bacterial cells in some genotypes at a region farther from the point of inoculation (although disease score was low) indicates that such genotypes may be susceptible to infection but can suppress or delay the effect of the pathogen on the plant. Such genotypes may be considered partially resistant since they show minimal damage despite substantial pathogen level. The bacterial populations in the advanced selections and cultivars were high at the region circumscribing infection, however, moving farther down to the base of the shoot; it appears that host defenses in the advanced selections could inhibit the movement of the bacterial cells through the shoot tissue unlike in the cultivars. This suggests that although the advanced selections showed necrotic symptoms after inoculation with Pss, they still had some level of resistance not present in the cultivars and thus, could be considered as sources of resistance to Pss in the sweet cherry breeding program. Previous studies (Mgbechi-Ezeri et al. 2013; Spotts et al. 2010b) reported that 'Regina' shows resistance to bacterial canker as demonstrated by visual expressions of necrotic symptoms in the field, greenhouse and in a detached leaf assay. In this study, we also found that the advancement of $P$. syringae pv. syringae in 'Regina' when compared with other known susceptible cultivars did not differ significantly in all the positions examined. In three environments (field, greenhouse and laboratory) and in different experiments and time periods, 'Regina' consistently displayed a low disease response. Moreover, despite the high level of pathogen populations in 'Regina' in positions farther away from the point of inoculation, the low disease response of 'Regina' was still evident. This indicates that 'Regina' may exhibit some level of resistance. More research is needed to determine if predisposing factors such as poor soil conditions, frost damage and high humidity may influence the disease response of 'Regina'.

\section{Conclusion}

This study has demonstrated that the disease severity in the sweet cherry cultivars including 'Rainier', 'Sweetheart' and 'Bing' was higher compared to 'Chelan', and 'Regina'. Based on the distinctive discrimination in disease response among genotypes with shoot inoculation, this method will be preferred for evaluation of sweet cherry genotypes for resistance to bacterial canker disease. All the advanced selections evaluated showed low disease response with 'AA', 'BB', 'DD' and 'EE' exhibiting some form of resistance by inhibiting the migration of bacterial cells from the point of inoculation to the base of the shoot. This result demonstrates that the advanced selections could be potential sources of allele donors for resistance to bacterial canker. The low correlation between fruit and foliar disease symptom expression is an indication that different genetic factors may be influencing bacterial canker in the fruit and other plant tissues. Pyramiding resistance alleles from both leaf and fruit tissues in new cultivars will be essential for effective disease control. Using visual disease rating alone may not provide sufficient information to fully determine the level of disease resistance in an individual genotype. Other parameters such as quantifying the pathogen population and level of migration from the point of inoculation may also be important.

Acknowledgements We thank Noel Munoz for tree budding and Mojtaba Chavoshi and Sue Watskin for assistance with greenhouse experimentation. This work was funded in part from royalty income from the sweet cherry breeding program. 


\section{Compliance with ethical standards}

Conflict of interest The authors declare that they have no conflict of interest.

\section{References}

Bedford KE, Sholberg PL, Kappel F (2003) Use of a detached leaf bioassay for screening sweet cherry cultivars for bacterial canker resistance. Acta Hortic 622:365-368. doi:10. 17660/ActaHortic.2003.622.37

Cameron HR (1962) Diseases of deciduous fruit trees incited by Pseudomonas syringae van Hall. Agric. Exp. Stn Tech. Bull. 66. Oreg. State Univ

Cameron HR (1970) Pseudomonas content of cherry trees. Phytopathology 60:1343-1346. doi:10.1094/Phyto-601343

Crosse JE (1966) Epidemiological relations of the pseudomonad pathogens of deciduous fruit trees. Annu Rev Phytopathol 4:291-310. doi:10.1146/annurev.py.04.090166.001451

Eddin KS, Marimuthu T, Ladhalakshmi TD, Rabindran R, Velazhahan R (2005) A simple inoculation technique for evaluation of cotton genotypes for resistance to bacterial blight caused by Xanthomonas axonopodis pv Malvacearum. J Plant Dis Prot 112:321-328

Garrett CM (1986) Influence of rootstock on the susceptibility of sweet cherry scions to bacterial canker, caused by Pseudomonas syringae pv. morsprunorum and syringae. Plant Pathol 35:114-119. doi:10.1111/j.1365-3059.1986.tb01989.x

Keane PJ, Kerr A (1997) Factors affecting disease development. In: Brown JF, Ogle HJ (eds) Plant pathogens and plant diseases. Rockvale, Australia, pp 287-298

Kennelly MM, Cazorla FM, de Vicente A, Ramos C, Sundin GW (2007) Pseudomonas syringae diseases of fruit trees: progress toward understanding and control. Plant Dis 91:4-17. doi:10.1094/PD-91-0004

Kover PX, Schaal BA (2002) Genetic variation for disease resistance and tolerance among Arabidopsis thaliana accessions. Proc Natl Acad Sci 99:11270-11274. doi:10. 1073/pnas.102288999

Latorre BA, González JA, Cox JE, Vial F (1985) Isolation of Pseudomonas syringae pv. syringae from cankers and effect of free moisture on its epiphytic populations on sweet cherry trees. Plant Dis 69:409-412. doi:10.1094/PD69-409

Latorre BA, Lillo C, Rioja ME (2002) Effects of temperature, free moisture duration and inoculum concentration on infection of sweet cherry by Pseudomonas syringae pv. syringae. Phytoparasitica 30:410-419

Lelliot RA, Billing E, Hayward AC (1966) A determinative scheme for the fluorescent plant pathogenic pseudomonads. J Appl Bacteriol 29:470-489. doi:10.1111/j.13652672.1966.tb03499.x

Lelliott RA, Stead DE (1987) Methods for the diagnosis of bacterial disease of plants. Blackwell, London

Mgbechi-Ezeri J (2016) Phenotypic screening of sweet cherry (Prunus avium L.) germplasm and identification of quantitative trait loci underlying bacterial canker disease. Dissertation, Washington State University
Mgbechi-Ezeri J, Johnson KB, Oraguzie N (2013) Effect of inoculum concentration, isolates and leaf age on bacterial canker disease development in sweet cherry (Prunus avium L.) cultivars. Abstracts, 7th cherry international symposium Plasencia, Italy 23-27 Jun. pp 163

Moore LW (1988) Pseudomonas syringae: disease and ice nucleation activity. Ornam Northwest Arch 12:3-16

Moragrega C, Liorente I, Manceau C, Montesinos E (2003) Susceptibility of European pear cultivars to Pseudomonas syringae pv. syringae using immature fruit and detached leaf assays. Eur J Plant Pathol 109:19-326

Olmstead JW, Lang GA, Grove GG (2001) Inheritance of powdery mildew resistance in sweet cherry. HortScience 36:337-340

Otta JD, English H (1970) Epidemiology of the bacterial canker disease of French Prune. Plant Dis Rep 54:332-336

Quesada-Ocampo LM, Hausbeck MK (2010) Resistance in tomato and wild relatives to crown and root rot caused by Phytophthora capsici. Phytopathology 100:619-627. doi:10.1094/PHYTO-100-6-0619

Renick LJ, Cogal AG, Sundin GW (2008) Phenotypic and genetic analysis of epiphytic Pseudomonas syringae populations from sweet cherry in Michigan. Plant Dis 92:372-378. doi:10.1094/PDIS-92-3-0372

Roche MM (2001) Development of an in vitro and modification of an in vivo bioassay to screen cherry genotypes for response to inoculation with Pseudomonas syringae pv. syringae. Thesis. Oregon State University

Santi F, Russell K, Menard M, Dufour J (2004) Screening wild cherry (Prunus avium) for resistance to bacterial canker by laboratory and field tests. For Pathol 34:349-362. doi:10. 1111/j.1439-0329.2004.00376.x

SAS Institute (2014) Statistical software version 9.4. SAS Institute Inc, Cary

Schaad NW, Jones JB, Chun W (2001) Laboratory guide for identification of plant pathogenic bacteria. APS Press, USA

Shane W, Baumer J (1987) Population dynamics of Pseudomonas syringae pv. syringae on spring wheat. Phytopathology 77:1399-1405. doi:10.1094/Phyto-77-1399

Sobiczewski P, Jones AL (1992) Effect of exposure to freezing temperatures on necrosis in sweet cherry shoots inoculated with Pseudomonas syringae pv. syringae or P. s. morsprunorum. Plant Dis 76:447-451. doi:10.1094/PD-76-0447

Sorensen KN, Kim KH, Takemoto JY (1998) PCR detection of cyclic lipodepsinonapeptide-producing Pseudomonas syringae pv syringae and similarity of strains. Appl Environ Microbiol 64:226-230

Spotts RA, Olsen JL, Long LE, Pscheidt JW (2010a) Bacterial canker of sweet cherry in Oregon: disease symptoms, cycle, and management. Ext Bull Oregon State University, pp. 1-4

Spotts RA, Wallis KM, Serdani M, Azarenko AN (2010b) Bacterial canker of sweet cherry in Oregon-infection of horticultural and natural wounds, and resistance of cultivar and rootstock combinations. Plant Dis 94:345-350. doi:10. 1094/PDIS-94-3-0345

Toyama TK, Ophardt DR, Howell WE, Grove GG (1993) New powdery mildew resistant sweet cherry. Fruit Var J 47:234-235

Vanneste JL, Reglinski T, Yu, Cornish DA (2013) Multiplication and movement of Pseudomonas syringae pv. 
actinidiae in kiwifruit plants. Acta Hortic 1095:117-122. doi:10.17660/ActaHortic.2015.1095.14

Vicente JG, Alves JP, Russell K, Roberts SJ (2004) Identification and discrimination of Pseudomonas syringae isolates from wild cherry in England. Eur J Plant Pathol 110:337-351. doi:10.1023/B:EJPP.0000021060.15901.33
Walker SJ, Bosland PW (1999) Inheritance of Phytophthora root rot and foliar blight resistance in pepper. J Am Soc Hortic Sci 124:14-18

Werner DJ, Ritchie DF, Cain DW, Zehr EI (1986) Susceptibility of peaches and nectarines, plant introductions, and other Prunus species to bacterial spot. HortScience 21:127-130 